\title{
2 The Rule of Rent: The State, Employers and the Becoming Urban Dweller in Northern Rhodesia Acting Across a Societal Field of Force, c. 1948-1962
}

\section{Introduction}

Urbanization means that people come to town. ${ }^{1}$ Their houses, all too often representing a promise rather than a materially available choice, have long become a staple of urban politics. After Northern Rhodesia had become implicated in the metropolitan war effort in the 1940 s, $^{2}$ it experienced one of the highest urbanization rates throughout the African continent. Moreover, ever since the first step of public investment in the colonies, the 1940 Colonial Development and Welfare Act, made available metropolitan loans, standards, accessibility, and politics of African housing incurred recurring debate and regulation, not only with regard to the Copperbelt region but with regard to other rapidly growing towns as well. At this time, the colonial state was fully established in Northern Rhodesia - albeit the number of expat administrators at no stage exceeded 300 persons. ${ }^{3}$

Even though the majority of white residents, be they from Britain, Germany, Greece, South Africa, Southern Rhodesia or other countries, did not have sustained experience in living in cities, the urbanization of Africans was frowned upon with particular suspicion by planning authorities, town clerks, district commissioners, representatives of municipal ratepayers, and town councilors officially in charge of turning the towns into livable space. While the so-called stabilization of labor became a declared aim of the time, a fundamental reservation pertained against African people's permanent residence in towns, let alone their entitlement to active social and political participation right there. The provision of social and infrastructural amenities was imaginable and, over time, consent emerged that it

1 This paper was written as part of the FWF-granted project "Employment-tied Housing in (Post) colonial Africa” (Project no. P29566-G28). For further information see: housing.univie.ac.at.

2 Kusum Datta, "Farm Labour, Agrarian Capital and the State in Colonial Zambia: The African Labour Corps, 1942-52,” Journal of Southern African Studies 14, no. 3 (1988).

3 Jan-Bart Gewald, "Researching and Writing in the Twilight of an Imagined Conquest: Anthropology in Northern Rhodesia 1930-1960," History and Anthropology 18, no. 4 (2007): 483.

Ә Open Access. (C) 2020 Kirsten Rüther, published by De Gruyter. (9) BY-NC This work is licensed under a Creative Commons Attribution-NonCommercial 4.0 International License. 
could be wise to have appointed Africans - less so elected ones - on advisory boards and committees. ${ }^{4}$ This was a paternal gesture along the lines that to advise was to learn while to rule was to teach. Hence, it was not intended to incorporate Africans politically or as fully rights-bearing citizens into the country's emerging conviction "that modern life and improved living standards could be open to all, regardless of race or history of subjugation." ${ }^{5}$ As a result, housing policies consciously withheld resources towards self-assertion or security of tenure. They made available accommodation in the form of social benefits and welfare tokens. Although today housing experiences are dominated by private renting, a free market philosophy, and the use of housing property to achieve financial gain, for the purpose of this paper, we have to engage with a completely different logic. State and employers who had no particular purview of investment or financially gainful speculation provided housing jointly and with a view of "stabilizing" labor.

In this scenario, the payment of rent became a relation that tied up in a web of power the metropolitan colonial state, its Northern Rhodesia government, urban bureaucracies, small as well as internationally operating employers, and the becoming urban dwellers - be they European, African or otherwise, be they immigrants from the South or elsewhere, colonial staff, industrial workers, or anyone else. This paper aims to show how a considerable number of acting bodies and individuals became tied up in the politics of rent. It sets out to detail how and to which effect these actors perceived each other through the experiences of rent payment and collection, and how they tried to make the best out of a system that was complicated and fraught with power biases as well as loopholes. The paper will furthermore assess the changes of some of these constellations as they occurred between 1948, when the African Housing Ordinance was passed, and 1962, when (after a complicated general election) European dominance ended and, with the installation of the first "black government", the path for Zambia's independence was set. $^{6}$

4 Draft memorandum of an unnamed member of Livingstone Municipality's Native Affairs Committee, June 1948, in: SP 4/1/33 Municipality of Livingstone, Minutes of Native Affairs Sub-Committee 1948, National Archives of Zambia (hereafter NAZ).

5 Frederick Cooper and Randall Packard, "Introduction," in International Development and the Social Sciences: Essays on the History and Politics of Knowledge, ed. Frederick Cooper and Randall Packard (Berkeley, CA: University of California Press, 1997), 9.

6 David Mulford, Zambia: The Politics of Independence 1957-1964 (Oxford: Oxford University Press, 1967), 56-106, 143-197; Bizeck Jube Phiri, A Political History of Zambia: From Colonial Rule to the Third Republic, 1890-2001 (Trenton, NJ: Africa World Press, 2006), 31-130, quoted term p. 113. 


\title{
Approaching the Field of Study
}

How did the variously implicated acting bodies and individuals relate to each other? Throughout the period under review, rent tied together a multitude of participants in what may be described as a "societal field of force."7 This concept captures how, between more than just two participants and their mutual relations, power biases and rule became enacted and shifted as a result of interactions.

\begin{abstract}
Rule, authority and mastery (Herrschaft) [conceived of] as a social practice - this phrase indicates a 'field of force' in which players establish relations between each other. They handle and deal with each other, even if at times they evade or try to ignore each other. It should be noted that this 'field' is not a static entity; its space and its contours change as players act out relations or refrain from them. Moreover, players are not autonomous subjects entering this 'field' from the outside. They evolve in exchange and negotiation to make other maneuvering forces feel their power, the stimuli they set and the demands they wish to impose or thwart. [...] This concept of a 'field of force' in which power is enforced and rule established or queried cannot be grasped in dual poles. Rulers and power holders face the ruled and the overpowered - rulers and power holders define themselves by means of holding sway over the ruled. And yet, rulers and power holders may depend on others while the ruled are more than passive recipients of rule(s) from the powerful. Most importantly, there are inequalities, contradictions, and differences between and among the rulers as well as between and among the ruled. ${ }^{8}$
\end{abstract}

This concept helps to capture the Northern Rhodesian situation where the state, various urban dwellers, administrations, engineers, the country's Municipal Association, and many more actors forced relations among each other - none of whom acted in either isolation, or an unchallenged power-holding position, or in hopeless subservience. Once an actor moved, the forces between the others in this matrix were recalibrated as well and, as a consequence, so were the exercise, experience, and expectations of legitimate power and rule. Rent and, more particularly, the acts of paying, withholding, or collecting rent worked as a medium that, as a material relationship as well as a more abstract idea, tied together actors in the variously emerging urban settings where people turned into urban dwellers. Thus, rent provides a useful lens through which to grasp the changing

\footnotetext{
7 E. P. Thompson, "Eighteenth-Century English Society: Class Struggle without Class?” Social History 3, no. 2 (1978): 151; Alf Lüdtke, "Einleitung: Herrschaft als soziale Praxis,” in Herrschaft als soziale Praxis: Historische und sozial-anthropologische Studien, ed. Alf Lüdtke (Göttingen: Vandenhoek \& Ruprecht, 1991). For reasons of readability and because I take over this term into my own vocabulary, I hereafter refrain from using inverted commas.
}

8 Lüdtke, "Einleitung”, 12-13. 
constellations of power and scopes for negotiation. The second section of this chapter will focus on these constellations.

Northern Rhodesia became a protectorate that was taken over from the British South Africa Company by the Colonial Office with an administration headed by a Governor in 1924. It was ever more successfully claimed as "their own" by settlers from various backgrounds, many of whom were British or Afrikaans-speaking farmers from Southern Rhodesia or South Africa. Increased European immigration - again from various parts of Europe, Southern Rhodesia, and South Africa - had prompted the consideration of improved housing for "Europeans" as early as 1942. ${ }^{9}$ Almost simultaneously, the Colonial Office in London circulated a position paper on the "General Aspects of the Housing Problem in the Colonial Empire" to its colonial governments. It pressed for reviewing existing housing legislation and recommended the introduction of town planning procedures and housing committees in each territory. ${ }^{10}$ In the colonial metropole, the Colonial Housing Research Group was initiated and chaired by the newly appointed director of the recently established Building Research Station to advise the Colonial Office on the organization of housing research in the colonies. Knowledge about building "in the tropics" became efficiently centralized, especially once each British colony assigned a technical officer henceforth to correspond with the metropolitan chief liaison officer. In southern-central Africa, the Central African Council appointed a Standing Committee on African Housing in 1945. It met consecutively in the respective capitals of Salisbury, Lusaka, and Limbe. ${ }^{11}$ Finally, in 1948, the African Housing Ordinance compelled employers to either build houses for their employees, including their legal wife and family, or pay rent for their accommodation to be erected under the aegis of local and municipal authorities. Funds were transferred from London to Lusaka and from there into the apparatus of colonial bureaucracy.

A significant number of areas became filled with houses by $1952 .^{12}$ Concomitantly, a "Report of Committee to Inquire into the African and Eurafrican

9 Telegram from Sir J. Waddington, Northern Rhodesia, to Secretary of State for the Colonies, 2 June 1942 and further correspondence, in: CO 795/123/4 Copperbelt Labour Supplies. Housing Question, 1942-1943, The National Archives, Kew (hereafter TNA).

10 Colonial Office, Housing in British African Territories (London: Her Majesty's Stationary Office, 1954), 10-11, in: LGH 1/16/53 African Housing. Atkinson Report, 1953, NAZ.

11 Minutes of the first meeting of the Standing African Housing Committee, Salisbury, 3-5 September 1945, in: CO 927/35/3 Housing Research, Central Africa, 1945-1947, TNA.

12 "Col. Wilson gives housing figures for Africans," Northern News 4 December 1952, and further records, in: LGH 1/16/52 Local Government: African Housing. General Policy, 1952-1953, NAZ. 
Housing Position in Lusaka" confirmed that much more housing was needed. ${ }^{13}$ Perhaps predictably, the number of houses built would always lag behind demand. In addition, despite increased government spending on African welfare, especially on housing, it was always much less than it could have been and, visibly for all, it was unimpressive compared with spending on services for Europeans. ${ }^{14}$ The standard of African housing ${ }^{15}$ projected buildings to last some 20 or 25 years, whereas loans were repayable over a period of 40 years. In the long run, this would develop into "an extremely serious position," "16 especially when the metropolitan and central governments divested themselves of the financial and administrative burdens of housing by transferring it to the responsibility of Local Authorities and individual municipalities. It was in fact in the mid-1950s, against the backdrop of housing provision becoming more burdensome and mounting political pressure from African nationalist politicians, that Africans became increasingly welcome into the Township Management Boards through which rent from so-called self-payers and fees or charges and services were to be collected. Such boards, staffed by Europeans and some Africans of honorary appointment, first existed for larger townships which were promised that, in case of successful development, they could develop into a municipality and establish their own municipal council. Up to that point, they would be subject to another municipal council. ${ }^{17}$

Even though rent represented a crucial form of tenure and mutual entanglement in towns, in academic literature it has largely been neglected. ${ }^{18}$ Where it was paid, rent was imbued with conflicts between private (and, to speak more

13 "Report of the Committee to Inquire into the African and Eurafrican Housing Position in Lusaka” [Nightingale Committee], discussed 5 May 1953, in: LGH 1/16/49 Housing for Eurafricans, 1949-1953, NAZ.

14 Andrew Roberts, A History of Zambia (London: Heinemann, 1976), 215-216.

15 Due to the idea that Africans would live in geographically determined zones, the so-called "African areas", the administration used "African housing" as a predominantly spatially related category. Africans who lived on educational establishments, in hospital wards, in police camps within European zones, or along the boundaries between officially designated zones (also called "open areas" according to Phiri, Political History of Zambia, 41) lived in buildings which were not necessarily submitted to the regulations of African housing.

16 Acting Commissioner for Local Government, S. W. Coleman, to Member for Lands and Local Government, 7 October 1958, in: LGH 1/8/1 Local Government: Municipal Association General, 1952-1963, NAZ.

17 Emmanuel Mutale, The Management of Urban Development in Zambia (Farnham: Ashgate, 2004), chapter 4 (book not paginated).

18 Carole Rakodi, "Rental Tenure in the Cities of Developing Countries," Urban Studies 32, no. 4-5 (1995). 
bluntly, often greedy) landlords, (usually impoverished) tenants, and state agencies incapable of or unwilling to provide housing. Not only in Tanzania or in Kenya, such landlords were often of Indian descent which contributed to rent becoming an important ingredient for racialized post-independent policies regulating housing property. ${ }^{19}$ Even though the state introduced rent limits or expropriated Indian landlords, this usually did not help the tenants if no additional housing became available. In Nairobi, for instance, unprecedentedly exploitative relations emerged after independence. They were an immediate result of a neglect of building houses for African workers in the colonial period. The persistent focus on ownership issues, however, has resulted in a distorted thinking in terms of tenement housing. Instead, the current debate focuses on unwanted "slums" rather than on achieving secure tenure through tenant-protecting rental agreements. ${ }^{20}$

Where rent was experienced as exploitative, boycotts became an issue. In South Africa, for instance, they turned into nationwide civil unrest throughout the 1980s and represented dwellers' responses to unaffordable rents and imminent eviction. Such boycotts also helped create a group awareness and a readiness to confront the state and municipality more generally. ${ }^{21}$ In Kenya, as well, where living conditions in the major cities were harsh, rent boycotts represented a moment of citizen mobilization. ${ }^{22}$ With regard to Northern Rhodesia, however, it is striking that colonial powers initially took rent-paying by tenants out of the power equation - to reduce conflict and to "deprive" urban dwellers of the reason for turning to organized protest against rent. Instead, Africans becoming urban dwellers in colonial Zambia boycotted in concerted action Asian and European shops, butchers selling bad meat wrapped in greasy paper, and elections, but there was no mobilization against rent issues. ${ }^{23}$ This aspect will be taken up in the subsequent section on the payment of rent as a relational force.

19 James R. Brennan, Taifa: Making Nation and Race in Urban Tanzania (Athens, OH: Ohio University Press, 2012), 1-20; see also William Cunningham Bissell, Urban Design, Chaos, and Colonial Power in Zanzibar (Bloomington, IN: Indiana University Press, 2011), 174, 238.

20 Marie Huchzermeyer, "Tenement City: The Emergence of Multi-Storey Districts Through Large-Scale Private Landlordism in Nairobi," International Journal of Urban and Regional Research 31, no. 4 (2007).

21 Matthew Chaskalson, Karen Jochelson, and Jeremy Seekings, "Rent Boycotts, the State and the Transformation of the Urban Political Economy in South Africa," Review of African Political Economy 40 (1987).

22 For a literary engagement with this important issue see, for instance, Meja Mwangi, The Cockroach Dance. 2nd edition (Columbus, Ohio: HM Books Intl., 2017).

23 Stephen A. Mpashi, Betty Kaunda (Lusaka: Longmans, 1969), 38-39. 
Only where residents looked back on long histories of settlement and tenancy, tenant associations emerged. This was the case in Bulawayo where, after 1951, a Rent Payers Association not only started to engage critically with the activities of the Location Advisory Board but also offered a platform for women to enter urban politics when board members were all male. ${ }^{24}$ For the majority of becoming urban dwellers, however, actual access to housing remained the more acute problem. ${ }^{25}$ People had to become rent payers first before they could organize as such and claim rights. As employers paid the rent for the majority of their generally low-paid African workforce, it remained difficult for tenants to position themselves independently and away from a stifling "master-servant" relation. It took a long time before they developed a self-conception as payers of rent and rates, despite the efforts of proponents of African nationalism who, immediately after the formation of the Central African Federation in 1953, forcefully drove social and political dynamics towards this direction.

A distinct situation emerged for African civil servants, many of whom aspired to occupy the same, or at least a similar, class position as their often Oxbridgeeducated colonial peers and superiors. Their rent was less subjugated to a master-servant relationship and at times not even to the specific regulations of an officially denominated "African area”. Quite frequently, and more tangibly however, a so-called "color bar" hampered their aspirations as will be described later. Many of these civil servants had a clear understanding of how Africans lived in most cases and how, at the same time, privileged white members of the Colonial Service lived, dwelled and resided. This is also the reason why the latter group's housing will come under scrutiny in the third section of this contribution on people moving places and residences. Of course, rent changed its significance over time and against the backdrop of heightened political tensions which occurred towards the imminent expectation of Zambian independence. This will be addressed in the fourth section of this contribution with a view to looking at political change through the vantage point of what happened with regard to housing and rent.

The contribution is based on documentary evidence gained from the National Archives in London and Lusaka respectively. Various departments of the colonial administration dealt with issues of housing. They collected evidence, papers, and memoranda from other interest groups, filed minutes from advisory councils,

24 Terence Ranger, Bulawayo Burning: The Social History of a Southern African City, 1893-1960 (Suffolk: Boydell \& Brewer, 2010), 171-174.

25 Amin Y. Kamete II, "Civil Society, Housing and Urban Governance: The Case of Urban Housing Co-operatives in Zimbabwe," in Associational Life in African Cities: Popular Responses to the Urban Crisis, ed. Arne Tostensen, Inge Tvedten, and Mariken Vaa (Stockholm: Nordiska Afrikainstitutet, 2001). 
legislation drafts and paid careful attention to newspaper coverage. This makes up for a rich and friction-bearing variety of perspectives and the documentation of controversies on issues related to the provision of housing and the ways tenants used and appropriated it. A serious impediment arises from the fact that the perspectives of the people for whom the houses were provided are rendered indirectly only. Moreover, the individuals and bodies that documented and archived material about housing were not necessarily inclined to use the same terms with reference to the same meaning. Planners, for instance, spoke of "African housing" as a spatially or typologically determined category, whereas settler politicians used the term "Africans" as a racial category intended to apply to people of color whom they did not want to differentiate either ethnically or with regard to social standing. Engineers referred to "housing types" rather than areas, people, or building projects, especially when houses were built and where the need for repair occurred. The colonial administration was interested in controlling areas and less so in how particular housing projects developed, at least not once they had been finished and started to expand or collapse. The Urban Advisory Boards, in turn, took individual houses and individuals' complaints as the starting point for dealing with housing issues and particular buildings. Today these individual houses cannot easily be identified, as there are often no street names or other indicators which would facilitate such a tracing.

This has major implications for the historian who wishes to trace the path of either a group of tenants or a set of houses allocated to one particular employer in a larger municipal area. Usually, we cannot follow a stringent trace but have to "hop around" between incidents, fragments, moments, and perspectives. Comprehending the categories pre-determined in the archival documentation, to read, in combined efforts, along and against the grain, we have to engage with the existing order as well as to try and overcome it. ${ }^{26}$ It is basically impossible to follow one set of actors, houses, or problems through multifaceted documentation which, each in itself, produces its own paper trails, categories, and units of observation. It is also not always clear how the key categories, terms, and phrases are to be wound down into clear racial, ethnic, social, or gender equivalents. Many denotations remain murky. As a result, as researchers and readers, we sometimes have to put up with a certain unease and remaining vagueness when we write and read about the rule of rent.

26 Ann Laura Stoler, Along the Archival Grain: Epistemic Anxieties and Colonial Common Sense (Princeton: Princeton University Press, 2009). 


\section{The Payment of Rent as a Relational Force}

In Northern Rhodesian towns, actors such as employers, the colonial and local governments, municipalities, engineers and, last but certainly not least, the workers and their families, as well as the aspiring African civil servants, enforced their powers, interests, and skepticisms upon each other. After the 1948 African Housing Ordinance ruled that employers would have to house their labor force or pay for its accommodation, this became accepted policy. It was seconded by the Employment of Natives Ordinance which dated back to 1929 and was amended in 1953. The ordinances bound large employers, such as the mines, the Zambesi Saw Mills or the Rhodesia Railway Company, in the same way as it bound the colonial government itself in whose service clerks, policemen, teachers, public work laborers, health officers, men in the postal and communication services, and many more stood. They also bound small employers such as market gardening companies, charcoal burning enterprises, fish or tobacco farming as well as small entrepreneurs in the transport business. With the Ministry of Mines and Labour (later renamed into Mines, Labour and Social Services) an agreement existed that, for workers earning less than $£ 10$ per month, employers paid the rent directly to local authorities or to the municipality, and only in 1963, as part of an incessant debate about paying an all-in wage, discussions started that this should perhaps be shifted to the amount of $£ 15 .^{27}$ The very few men whose earnings exceeded this amount were expected to pay themselves - again, only after exemption had been granted through the Commissioner of Labour and Mines. Rent thus tightened relations between state and employers and turned workers into recipients of the fruits of that power web - as long as they were formally employed. In cases of unemployment, prolonged sickness, and after retirement they were removed from that tripartite relation and had to fend for themselves. ${ }^{28}$

The system did not run smoothly. The legislation was modeled on an understanding of paternalist rule, as in idealized circumstances it assumed legitimacy between a well-meaning, perhaps even feudal, master and obedient and, in the best of cases, cared-for servants. Colonial paternalism may have proved attractive from the viewpoint of the British colonizers for whom it produced a re-encounter with their own pre-modern past and a largely outmoded form of rural social organization..$^{29}$ It was inappropriate, in many ways, to meet African

27 Report of the Secretary to the Executive Committee, 1 October 1963, in: LGH 1/2/72 Township Regulations, 1963-66, NAZ.

28 For a general overview see Roberts, History of Zambia, 187-194.

29 On paternalism as a backward-looking myth or ideology see Thompson, "EighteenthCentury English Society,” 134-137. 
people's expectations and aspirations to move towards modern life and improved living standards. It was also inappropriate for employers' capitalistdriven ambitions. Reading across a multitude of files it appears that in most cases employers other than the internationally operating mines were reluctant to bind capital in company housing and organize resources for the upkeep of that asset. They generally preferred to pay rent and keep the wages accordingly low. Sometimes they offered housing allowances if municipal housing was unavailable. For employers, generally, it virtually paid much more and would have sufficed that, in dealing with the moderate trade union leader Lawrence Katilungu, in the decade between 1949 and 1959 the Northern Rhodesia Government successfully kept trade union affairs and politics in separate compartments. The government's effective curbing of trade unionism secured the persistence of a low-wage economy, and workers had no possibility of falling back onto an organization which would have pushed the expression of their frustrations. ${ }^{30}$ In fact, better schooling would have assisted employers far more than housing offers to get hold of the labor and skills they required.

Once the Central African Federation had come into existence and the African nationalist parties asserted their position between 1953 and 1957, it would turn out that large employers, such as the mining companies, devised their own policies to maintain power in the region. Rather than using housing for their political agendas they started to talk to leaders and to support the Federation government and offered to African nationalist politicians loans or financial incentives. ${ }^{31}$ They allowed skilled African miners into jobs previously held by Europeans - albeit for a third or even less of what white miners had earned. ${ }^{32}$ Even though rent was an issue of daily concern, it did not become a topic "appropriated" by the workers. Smaller enterprises went on as before. In the end, none of all these employers' art of domination really depended on the provision of houses. They went by it as long as the colonial legislation required them to do so. They refrained from undermining the authority of the colonial state, which supported the interests of various employers and tried to get them on board, as best as they could. However, the more mobile employers, such as

30 Mulford, Zambia, 170-177.

31 Andrew Cohen, "Business and Decolonisation in Central Africa Reconsidered," Journal of Imperial and Commonwealth History 36, no. 4 (2008).

32 Ian Phimister, "Proletarians in Paradise: The Historiography and Historical Sociology of White Miners on the Copperbelt," in Living the End of Empire: Politics and Society in Late Colonial Zambia, ed. Giacomo Macola, Jan-Bart Gewald, and Marja Hinfelaar (Leiden: Brill, 2011), 151-152; and Jane Parpart, Labor and Capital on the African Copperbelt (Philadelphia: Temple University Press, 1983), 136-137. 
the Rhodesia Railways, the Zambesi Saw Mills or the various construction companies always lagged behind with the provision of housing according to standards due to their changing sites of business activity.

The postwar colonial state, despite its paternal gestures, extended control over subjects and becoming citizens to demonstrate its rationality and efficiency. Disciplining the populace, bettering their living conditions and making male labor subservient and content in the comforts of family homes became important initiatives in order to intensify the state's outreach. Colonialism represented an authoritarian form of rule. More acutely than before, the state was felt in personal surroundings. As a result, workers became eager to participate in the promises which existed nevertheless and claimed opportunities for themselves. ${ }^{33}$ However, even though liberally minded sections of the colonizers promoted the idea of a new African middle class to emerge, colonial authorities more generally lacked the inclination to let an independent and rights-demanding African citizenry emerge. Ideally, the majority of Africans would arrange themselves and cooperate with colonial rule, so that despite discontent and friction they would not have to face open challenges or resistance. To achieve this, it had to leave enough scope for subservient people to carve out and make use of economic, cultural, and social niches in which they could pursue family life and indulgence in social welfare activities (even though these social welfare clubs became the very foundations of organized political activities). For this reason, it definitely made sense to make rent a concern to be agreed upon between employers and local authorities and to turn housing into a social benefit rather than an asset that families would consider their own. Naturally, this was resource-intensive. Over the years, the official housing policy improved housing and enhanced certain standards for some rather than for all. ${ }^{34}$ The majority of the urban working-class people continued to make their own housing arrangements. ${ }^{35}$ And yet, as long as rent was not paid by a

33 James Ferguson, Expectations of Modernity: Myths and Meanings of Urban Life on the Zambian Copperbelt (Berkeley: University of California Press, 2001).

34 It has been argued that in rural development policies, the minority of "modernizing" farmers, the so-called "emergent farmer," rather than the majority of poor and small-scale producers were intended as recipients of support. See Kate Crehan and Achim von Oppen, "Understandings of 'Development': An Arena for Struggle. The Making of a Development Project in North-Western Province," in Planners and History: Negotiating 'Development' in Rural Zambia, ed. Kate Crehan and Achim von Oppen (Lusaka: Multimedia Publications, 1994). This pertains to the urban situation as well, where a small number of formally employed African workers became the recipients of housing.

35 Karen Tranberg Hansen, Distant Companions: Servants and Employers in Zambia, 1900-1985 (Ithaca, NY: Cornell University Press, 1989), 120. 
large number of employees themselves, it remained difficult for them to claim permanence in their new surroundings.

Of course, there was the wish of those who came to the towns as workers to achieve entitlement to their new place, to be able to pay the required rates and taxes, to live in decency, and to be able to support a family as well as other aspirations pursued either in town, back home, or in both places. These people were prepared to submit to the supervision and tutelage of employers and towns. As evidently public spending went into urban and industrializing areas rather than into rural areas and agriculture, cash and the promises of wage employment were to be tapped right there - often to the detriment of rural areas. Rent, paid by others, inhibited permanence in the towns. It tied Africans, especially formally employed African workers, to political authorities as clients rather than independent town dwellers. And in fact, once direct political representation became a concerted claim in the colony, the paying of rent was used to denigrate African tenants as unpropertied and thus unqualified for the franchise.

In a perfectly controlled setting, rent thus enacted would have kept tenants in check. Laborers, however, who lost their families' accommodation in the case of unemployment, when they changed employers or when official housing was unavailable, arranged to live in what the colonial administration labeled as "private locations," "unauthorised settlements" or, in the case of Livingstone, even "loafers' compounds." 36 As many stayed in such places even after taking up work with another employer, these sub-scenarios of power and dependency substantially inhibited the purview of the state-employer dominance in the Northern Rhodesian field of force. Building standards and living conditions of "unauthorised housing" did not receive official approval. The places were often, though not always, overpriced. Colonial state departments were prone to losing grip of the situation.

There are always difficulties about having little islands in a Government area leased to private individuals. Arguments start over the length of term of the lease before it is granted, continue about the type of building to be erected, and only cease when the lease is surrendered or falls in - and even then only after a final haggle about payment of compensation. ${ }^{37}$

36 MLSS 1/24/7 Labour Department. African Housing (Unauthorised Locations), 1955-1961, NAZ; LGH 1/1/30 Unauthorised Locations, 1960-1968, NAZ; MLSS 1/24/2 Housing. Native Locations. Private Locations, 1944, NAZ; SP 4/1/30 Municipality of Livingstone. Minutes Native Affairs Sub-Committee Meetings, 1947, NAZ.

37 Director of Lands and Surveys, Livingstone, to Secretariat, Lusaka, 13 March 1950, in: LGH 3/2/9 Livingstone: Areas and Boundaries, 1951-59, NAZ. 
Employers protested against having to pay rent to the Local Authorities for workers who lived in such surroundings. ${ }^{38}$ They actually found it difficult to keep track of where their laborers lived just as rent-collecting Local Authorities did not always know which laborers were paid for by their employers, who had to pay rent themselves, and how many workers might live in one house (and would have had to pay rent for it, too). Thus, the collection and payment of rent evolved into a highly arbitrary activity:

Half the men in Kalingalinga are unemployed, I was told by Africans there. So when the rent collector comes round for the 10s. a month rent, the jobless Africans have to borrow from their employed 'brothers'. The rent collector, incidentally, lives in 'Capital House', as Africans described his abode to me. The rent collector is the agent of the landowners chiefly Indians - and besides collecting rent he visits each house giving any orders or instructions the landlords of the five sections of the compound wish to make. ${ }^{39}$

As problematic as living in such places proved to be, it opened up scope for selfemployment, for living near one's relatives and, perhaps, some other advantages not documented in the archival fold. The documents, rich as they are, absorb and swallow much of what we would like to establish with more clarity. We cannot actually retrieve from the archival documentation how many workers preferred to pay higher rent for standardized homes. Many Africans, though, workers, civil servants, and incipient entrepreneurs, so it appears from reading the debates across the files, would have preferred to pay their own rent. They wanted to pay less rent for old houses with leaking roofs and in need of repair - houses they could probably have afforded more easily in comparison to the newer two- or three-roomed houses of different standards. ${ }^{40}$ Others argued that they preferred to receive a cash allowance they could have spent on items more desirable than rent. Such responses indicate a wish on the part of workers and town dwellers to assume control over resources. They also indicate changing expectations with regard to necessary expenses and desirable commodities. From the record, it is unfathomable when and how exactly such attitudes may have changed. But attitudes in 1957 differed from what they used to be in 1948. People then consistently complained about a lack of infrastructure, wished to retain their houses in times of unemployment, had more encompassing consumer wishes and desired to take

38 Labour Officer's Office to Labour Commissioner, Lusaka, 9 February 1956, in: MLSS 1/24/7, NAZ.

39 "Rough - But Alive”, Central African Post, 26 October 1960, in: MLSS 1/24/7, NAZ.

40 SP 4/6/10 Urban Advisory Councils and Welfare Associations. General, 1952-1956, NAZ. 
decisions about the areas in which they lived. ${ }^{41}$ As becoming urban citizens, they claimed entitlement and expressed their aspiration towards participation in the towns. A sense of entitlement, participation, and access to consumer commodities crystallized around rent, which was paid in money, but again, at least in the archival record, rent did not arise as a topic of contention pushed from either town dwellers, workers, civil servants or the advisory councils. Rent was a tie, and it was tied itself to many other, more immediate claims to living rightful in an urban context.

Between the metropolitan government committing itself to a rhetoric of multiracialism, the operations of the settler immigrants, many of whom openly favored either racist policies or liberal positions, the Federation government which insisted on independent action from the metropole, and the locally situated municipalities, an inherent web of tensions is worth of note. The colonial bureaucracy was staffed with Oxon graduates who seldom feared job competition and who were often more well-disposed to African people's aspirations. They frequently resorted to open paternalism and to patronizing attitudes. ${ }^{42}$ This was different with European and South African whites who envisaged their lives and prosperity permanently in Northern Rhodesia and who were particularly suspicious of any political interference from the Colonial Office back in London. London, in turn, even though critical of growing settler antagonism, also felt the ambiguous task to protect this group. Lacking desired liberality, they were nevertheless deemed superior to Africans who, notwithstanding, had a right to progress and advance.

With the introduction of the Central African Federation's racially discriminatory legislation, a fear of a legally inscribed racism into Northern Rhodesia's society prompted the rise of African nationalism. This African nationalism was borne by the African National Congress (ANC) in the initial years. After the breakaway of the more radical Zambia African National Congress (ZANC) in 1958 (which a year later became the United Independence Party (UNIP)), competition between two versions of African nationalism intensified. With regard to urban policy and planning, white and European settlers from the South were much more effectively represented in the Municipal Association of Northern Rhodesia. This body campaigned ruthlessly for privileges along the lines of South African apartheid rules. They advocated spatial separation and segregated administration setups and did not encounter serious resistance in the Urban Advisory Councils and

41 "Take-note motion" of the Brown Report, Mr. Cousins, Nominated Official, Hansard 7 August 1957, in: MLSS 1/24/14 Employment of Natives and "Housing Conditions", 1957-1959, NAZ.

42 Gewald, "Researching and Writing," 35. 
African Affairs Committees, which were often toothless tigers on the basis of contested legitimacy among the constituency they were due to represent.

After 1940, in an act of welfare and development, the Colonial Office in London had started to channel funds to the colonies, more particularly, to the newly founded Department of Local Government and Social Welfare (at times also named the Department of Local Government and Housing), for the erection of housing. For a brief period, the philosophy of cost-recovery was substituted: to overcome the problems attached to a low-wage economy, and to persuade employers into the scheme, they suggested the provisional introduction of subeconomic rents. ${ }^{43}$ When the metropolitan government became more reluctant to colonize, because it had to keep settlers at bay and to finance increasing welfare commitments, housing was transferred into the responsibility of the colonies themselves. This included the handling of finances. Debates changed almost immediately once it became clear, shortly after 1957, that central funds would soon be withdrawn. All of a sudden, by 1959, arguments about economic rents and the payment of rent surfaced as a precondition for turning tenants into rightsbearing citizens - as will be commented upon further below. Rent then became a strand tied to which the more important issue of citizenship moved to the fore.

There is at least one more force to be taken into consideration on the Northern Rhodesian field of force. For the implementation of housing programs, the colonial administration relied on techno-scientific expertise. Already in its initial stages of the late nineteenth century, the planning professions had reflected a strengthened role for the state which went hand in glove with techno-scientific management approaches to growing populations in rapidly industrializing nations. ${ }^{44}$ After the ending of the Second World War, engineering and planning professionals tapped the new knowledge emerging from building research and coordinated it through the metropole. When engineers entered the Northern Rhodesian societal field of force, they advocated "modern" means, such as zoning, to achieve the control of the urban population. This was a tool of control which was detached and worked through de-emphasizing the logic of personalized rule. The South African writer Ivan Vladislavic crisply captures this attitude

43 Northern Rhodesia Colonial Governor, J. Waddington, to A. B. Cohen, Colonial Office, 13 February 1946, in: CO 927/35/3 Housing Research, Central Africa, 1945-1947, TNA. For the debate in Livingstone see, for instance, Municipality of Livingstone's Report of meeting with Commissioner for Local Government and African Housing, L. W. G. Eccles, and Executive Engineer, A. M. Dibble, 17 October 1946, in: SP 4/3/6 Municipality of Livingstone, Native Affairs Sub-Committee, 1946, NAZ.

44 Robert K. Home, Of Planting and Planning: The Making of British Colonial Cities. 2nd edition (Oxford: Routledge, 2013), 36-61. 
in two of his fictional characters, a sanitary engineer who "always found it strange to set foot for the first time in a place he knew from the plans," and a public planner who pondered that "we don't have relations with the public. We have relations with local governments." 45 This was another strategy to conceptualize the power biases of urban planning without the tenant or urban dweller being represented in government institutions or in the colony-wide Municipal Association.

Couched in a lexicon of rationality and neutrality - thus overriding conflict, interest and bias - the language of planning and engineering left a significant imprint on the way in which actors in the Northern Rhodesian field of force were able to engage with regard to housing and spatial planning. Even wellmeaning politicians learned with surprise from some of their African colleagues that, for instance, rather than speaking of different zones and areas, Africans referred to "going down Colour Bar Road" when commenting upon racialized urban planning legislation.

You talk to an African, a fairly leading citizen, perhaps an African Civil Servant or something like that, and he suddenly says, 'I was going down Colour Bar Road the other day'. Well now, you learn something that you did not know before. You have seen the road, you never realised that the tarmac stopped at one place and it went on as an earth road; you never even noticed it. [...] [Y]ou realise that something should be done about it; and in fact it ... was taken up by the hon. Member for Lands and Local Government. ${ }^{46}$

Mr. Franklin, the Member for Education and Social Services in the Northern Rhodesia Legislative Council, who made this remark, still thought in terms of material infrastructure and built environment, while his interlocutor probably meant to describe racial discrimination more generally. In fact, the language of engineering earned itself a reputation for de-emphasizing the human element which, up to today, remains a major effort to reintroduce. ${ }^{47}$ Instead, their lexicon and discourse revolved around standards, building material, and measurements, not even rent, ownership, and subsidization which preoccupied colonial politicians in the first instance. Hardly ever did anyone mention African people's right to permanence in the towns as urban dwellers. But Africans, civil servants, workers, and councils pressed hard to shift the more technically phrased debates to

45 Ivan Vladislavic, The Exploded View (Cape Town: Umuzi, 2017), 52, 56.

46 Mr. Franklin, Member for Education and Social Services, in LegCo debate, Hansard 92x, 7 August 1957, in: MLSS 1/24/14, NAZ.

47 Nicholas Sungura, "Der Faktor Mensch bei der Risikosteuerung öffentlicher Bauvorhaben in Kenia” (Dr. Eng. diss., University of Hannover, 2016). See also the interview with Nicholas Sungura and Marlene Wagner in this volume. 
agendas in which they demanded their employers and fellow politicians to account for policies of inequality in appropriate language. ${ }^{48}$

A group whose interactions with European holders of power intensified towards the late 1950s, and who represented yet another player on the Northern Rhodesian field of force, was African civil servants. The ways they voiced their aspirations is therefore particularly indicative with regard to the evolvement of power relations as crystallized through understandings of housing and rent. With the exception of hospital staff, police, and teachers at higher educational institutions, civil servants were not housed in their own compounds but lived interspersed with other Africans to whom they were intended to serve as role models. Safeli Chileshe, member of the First African Representative Council and elected to the Legislative Council in 1954, did not receive accommodation in a township when starting his career as a teacher but was put up in a hurriedly constructed house on the western side of the township, on Burma Road, which served as a dividing line between African compounds on the West and artisans of European extraction on the East. Chileshe remembers this abode as "no-man's land house." 49 In the medium and higher ranks, African civil servants were entitled to better-type housing. This was built in distinct places, sometimes in the inbetween spaces bordering either European residential areas or large roads leading up to European housing areas. The accommodation of individual Africans of senior rank would become even more complicated once African civil servants became integrated into civil service in larger numbers and at higher ranks. It was through them that the privileged housing circumstances for Europeans come into view, as they served as a reference for those to whom this kind of housing was not (yet) available but who attained prospective entitlement to it through the years. It was in this group that the racism of housing policies mattered tangibly, as many Africans aspired to higher ranks but were outdone in terms of material wealth by whites of lower social or educational rank. As John Mwanakatwe, who achieved a distinguished record in government service, first as an education officer and later as the first African secondary-school principal in Northern Rhodesia, noted in his autobiography:

I had serious reservations about the attitude of the less educated white clerical officers and businessmen. Such white men and women enjoyed privileges - salaries, housing and

48 Various minutes and reports in: SP 4/1/26 Municipality of Livingstone. Minutes. Public Works - Sub-Committee, 1946-1955, NAZ.

49 Jonathan H. Chileshe, Alderman Safeli Hannock Chileshe: A Tribute to (the Man), His Life, and History (Ndola: Mission Press, 1998), 65. 
social amenities not because of their superior abilities or qualifications, but simply because of the colour of their skin. ${ }^{50}$

In Northern Rhodesia, society was interdependent, even though by far not integrated. It therefore helps to look at housing involvements not just of Africans but of others as well. Housing for Africans was indeed embedded in a polarized society in which a plurality of extremes and nodes, an unevenly structured fabric soaked with inequality, channeled access to housing. The issue at stake was not primarily rent, but housing itself, its physical provision as well as the way it signified privilege.

\section{People Moving Places and Residence}

What was this privilege demonstrated in the colony? Fresh from the British metropole, the young colonial servants' discourse was all about largeness, unavailability, and being prepared to move when they talked about housing. They were a "wandering flock," part of "Northern Rhodesia's migrating herds." 51 For young men, Lusaka nevertheless was a place of promise as compared, for instance, to any of the dull Lancastrian towns back home. If unmarried, colonial servants were not entitled to housing of their own immediately upon their arrival in the colony. While being based in the Government Rest House, some took it as a virtual sport to find opportunities for house-sitting the most splendid and wellstaffed mansions of senior colleagues for the time they went on leave. For the occupiers of such large state-provided homes, in turn, it was advantageous to hand over their house to a known or trusted person. This ensured that they would not have to fully move out of the allotted house. As leaves were long colonial servants acquired five days of holiday per month so that after three years these accumulated up to 180 days plus 42 days of travel - housing committees were keen on putting new arrivals or people from the waiting list into the empty houses. ${ }^{52}$ Sparing the host the burden of having to pack personal items away and offering them the opportunity to repossess the same house after their

50 John M. Mwanakatwe, Teacher, Politician, Lawyer: My Autobiography (Lusaka: Bookworld Publications, 2003), 67. In this memoir, it becomes clear that at least in later years members of the African new elite also read the memoirs of the older British civil servant group, see especially pp. 44-45.

51 Frank Bennett, Under an African Sun: Memoirs of a Colonial Officer in Northern Rhodesia (London: Radcliffe, 2005), 97, 98.

52 Bennett, African Sun, 31-33, 72. 
return, the young Frank Bennett managed to dive into the promises of colonial abundance so that, already in youthful years, he enjoyed a status unaffordable to him back home. While his life was (still) impermanent, he moved into the appropriate networks. This set him on the track of upward social mobility. Other people also moved in and out in a world that held more than permanent possessions. And even though in the living room of expatriates' houses the furniture was hard, once having received some curtains for adorning at least the windows, the houses received a personal touch and became the basis for the pursuit of an unknown lifestyle, with cooks, gardeners, and other servants. ${ }^{53}$ Rent was calculated on the basis of these civil servants' salaries rather than in relation to the luxuriousness of the respective house they had grabbed from colleagues. If they wished, they moved across a masculine imperial world in which they were able to "fl[ee] from domesticity." 54 They added adventure to their lives or, if they preferred otherwise, created promises to their evolving families.

Housing experiences of British colonial officers in Northern Rhodesia thus resembled what "empire families" felt elsewhere and conveyed an important experience via letters back home. They moved from one place to another, packed repeatedly and each time filled new accommodations with another set of cheaply purchased furnishings. They always rented houses, or had the government rent the houses for them. Accumulating relatively few pieces of furniture and keeping a small quantity of portable decorative objects only, many of them, however, looked forward to being rewarded with a small English house upon retirement. ${ }^{55}$ The house "at home" represented an expectation. More than once, this turned into plain disappointment, as returnees from Northern Rhodesia soon realized.

53 Mick Bond, From Northern Rhodesia to Zambia: Recollections of a DO/DC 1962-73 (Oxford: Gadsden Publishers, 2014), 13-28.

54 John Tosh, "Imperial Masculinity and the Flight from Domesticity in Britain, 1880-1914," in Gender and Colonialism, ed. Timothy P. Foley et al. (Galway: Galway University Press, 1995). Tosh's observation has been made for an earlier period, but it holds for this context as well.

55 Elizabeth Buettner, Empire Families: Britons and Late Imperial India (Oxford: Oxford University Press, 2005), 189-194. As regards the situation of workers in Northern Rhodesia classified as "European", it is a commonplace that white immigrants from South Africa were less secure in their social position and used racism and racial politics in different ways to better and back up their position. For most of the 1950s, the real earnings of white artisans were approximately 20 times greater than those of the black workers they supervised; see Phimister, "Proletarians in Paradise", 154. On the mines, earnings were good, housing was provided, European workers could buy cars and go to bars or sports facilities. Sixteen percent of them envisaged in the late 1950s to stay beyond retirement; see p. 157. So, settlement remained largely temporary - albeit lengthening - sojourns. In our project work, up to now, we have not been able to locate documentation in which they would have voiced their particular grievances or aspirations. 
Returning civil servants, even after brief spells only in colonial territories, stumbled into "the smallest living room I had ever seen in my life" back home or despaired when, on leave, they had to share places with their nagging parents. ${ }^{56}$

For others, housing functioned as a way of beginning to feel settled. This was especially the case if officers wished to start a family and adamantly preferred any short-term placement to boundless rootlessness. Mick Bond, a district commissioner who joined the Colonial Service when it was already clear that the empire would soon dissolve, rejoiced that "Mporokoso quickly became ku mwesu (at ours, at home). This was where we were to spend our first two years in Africa, the first two years of our married life, and for me my first paid employment." ${ }^{57}$ Once transferred to another place, however, he and his wife would lose sight of those with whom, for a couple of years, they had dined and maintained the ties of neighborly communion. The world of the colonial service was mobile. In the archival files, though different from individually published memoirs, letters are replete with requests submitted by men who were tired of being shifted around and of living in desolate buildings nobody regarded as their own.

The difficulty of residing in temporary premises, will, I am sure, be appreciated by all members of the Housing Committee, the comfort of one's home and the satisfaction of good permanent housing reflects not only in the creature comforts, but also in the efficiency, enthusiasm, and concentration that one can apply to the daily task. ${ }^{58}$

Despite urgently needed housing on all sides, the government spent visibly more resources on white privilege than on the needs and demands arising from Africans. Moreover, while housing requests by Europeans became part of the archival documentation, the requests by Africans directed to the African Urban Advisory Councils are available in mediated form only. On the advisory councils, members spoke to the district officers about complaints they had received but these spokespersons often did not enjoy much trust or high regard in the eyes of the dwellers whose concerns they represented. ${ }^{59}$

56 Bennett, African Sun, 240; Bond, From Northern Rhodesia, 147.

57 Bond, From Northern Rhodesia, 13.

58 H. Bradford to Mazabuka Housing Committee, 20 December 1957, in: SP 4/3/14 Housing Committee, Mazabuka, 1955-1958, NAZ.

59 For Southern Province, for instance, see LGH 3/25/17 Urban Advisory Councils, Welfare Associations General, and Other Associations, 1956-1960, NAZ; SP 4/6/10 Urban Advisory Councils and Welfare Associations - General, 1952-1956, NAZ; SP 1/4/14 Livingstone African Urban Advisory Council 1958-1959, NAZ. 
There is additional evidence in a handful of memoirs, popular biographies, and autobiographical accounts written by Zambians - often with a view to building and strengthening the independent nation. More than one of them emphasized that their fathers actively built the colony in brick and stone. Safeli Chileshe's father, for instance, used to be a bricklayer. His family recalled that he had helped erect the Livingstone statue which faced the Victoria Falls Hotel and that he had built the very steps which, years back in 1947, the British royal family used to disembark from the Flying Boat onto the banks of the Zambezi River. The Chileshes understood this as their founding father's contribution to the forming of the country's landscape. ${ }^{60}$ John M. Mwanakatwe's father worked with the Public Works Department and thus contributed to the building of the first secondary educational establishment, Munali School, an institution from which the aspiring post-independence elite, and also Mwanakatwe himself, emerged as some of the men responsible for building the independent nation. ${ }^{61}$ And Robinson Nabulyato, member of the Northern Rhodesian Legislative Council and later speaker of the National Assembly of Zambia, self-confidently stated that

[i]n colonial Zambia, the missionaries who brought education and medical care to the rural people never had to put up schools or clinics or the houses for their teachers and medical workers. These were built by the villagers, who appreciated the services rendered on to them. The colonial government, too, drew upon self-help, especially when 'Native Courts' were built in many chiefly capitals from the late 1920s. Even when permanent materials were required, the local people provided the bricks, while the government gave them the corrugated iron sheets, doors, windows and so on. ${ }^{62}$

Nabulyato's narrative comprises a pinch of rhetoric about so-called self-help, an important phrase in the 1970s and 1980s when everybody would speak about development in a language that differed from previous discursive patterns.

Read against the playful grabbing of houses by greenhorn colonial officers, these statements mark a counter position which points out that even though Africans did not share the same availability of resources as their colonial rulers, it was them who actually commanded building expertise and that it was them who actually built the houses materially - with their labor, accommodating openness, and dignity. To a certain degree, it shows the reluctance, even though not outspoken resistance, to accept being drawn into the colonial relations of power and rule via rent, not just by avoiding and evading it, but by formulating

60 Chileshe, Alderman Safeli Hannock Chileshe, 29.

61 Mwanakatwe, Teacher, Politician, 1-5, 9.

62 Robinson M. Nabulyato, African Realities: A Memoir, ed. Giacomo Macola (Lusaka: The Lembani Trust, 2008), 63. More autobiographies wait to be investigated. 
an alternative discursive trope. Certainly, rule was not omniscient. There were options and avenues of circling around. There was, in fact, an "addressivity that neither vilified nor vindicated colonialism."63 Even if individuals did not own a house and even if they were not able to claim participation through the payment of rent, some at least were in a position to lay claim to the nation, the town and its surroundings through their fathers' occupations one generation back. In the political debate, however, one major argument to prevent people from participation in urban issues and direct representation was that they were no proper ratepayers. It is to this scenario that the next section will turn.

\section{The Changing Significance of Rent Against the Backdrop of Heightening Political Tensions}

The significance of rent changed over time, and its meaning needed to be worked out against shifting political, economic, and social circumstances which were tightening after the establishment of the Central African Federation in 1953 and especially towards the achievement of independence after 1957. One perspective that has, as of yet, been neglected in this contribution is how relations, mutual perceptions, and obligations as well as efforts to set new agendas evolved over time, thus reshaping the temporal dimensions of the Northern Rhodesian societal field of force. A field of force is not just spatial. It has temporal dimensions as well. In this regard it is especially rewarding to trace the meaning of rent in the intensifying debate about political responsibility and (direct) African representation in municipal, federal or colonial governing bodies and, more particularly, the way it was entangled with handling rent issues.

Prior to 1953, neither the educated African minority nor politically mobilized workers and unions were keen on overthrowing the colonial state. To some extent, they yielded into the dictum that sitting on advisory boards would train and instruct them in administrative procedures even though it barred them from proper decision-taking and did not necessarily make them popular with the mass of people they represented. The majority being largely subservient African members of governing and consultative bodies, many accepted their roles as informants, brokers, and go-betweens rather than

63 Harri Englund, "Anti Anti-Colonialism: Vernacular Press and Emergent Possibilities in Colonial Zambia," Comparative Studies in Society and History 57, no. 1 (2015): 231. 
being rebels when it came to issues such as education, sanitation, and township organization. The African Representative Council, established as the highest African consulting body in 1946, was presided over by the Secretary of Native Affairs and, after 1948, elected two of its members to sit on the Legislative Council but had no executive powers. The members of that council articulated African opinion and criticized the so-called "color bar" but did not grab the chance to act as immediate achievers of African interests and aspirations. In the end, however, it was here that official delegates of the African people fiercely protested against the establishment of Federation, as they were even weaker represented on lower boards and municipal councils. ${ }^{64}$

Impending voicelessness was worse with other bodies, such as the Housing Area Boards, established after 1954 in an advisory capacity to Local Authorities. Assigned to European or white chairmanship, the boards were responsible to the African Affairs Committees, adjunct to each Municipal Council and becoming largely impotent under the Federal Government in Salisbury which, in the end, decided about the ordering and well-being of the town, its infrastructure, and its African areas. African township residents could take their problems, sorrows, and complaints to these official forums. Most Housing Area Boards, however, suffered from a lack of legitimacy with the constituencies they were supposed to represent. ${ }^{65}$ Township dwellers were especially suspicious of the nominated members, particularly when they turned out to be puppets of the powers that appointed them rather than advocates acting on behalf of the evolving needy urban African constituency. Becoming politically aware and increasingly articulating their voice through better-organized parties (ANC and ZANC/UNIP), many Africans of Northern Rhodesia became less compromising about direct representation. Consequently, the ratio between nominated and elected members became an issue of dispute - white officeholders arguing they were the ones who financed the towns as ratepayers while Africans, devoid of property, did not qualify for the franchise. ${ }^{66}$ It is interesting to note that in South Africa, for instance,

64 Jotham C. Momba and Fay Gadsden, "Zambia: Nonviolent Strategies Against Colonialism, 1900s-1960s," in Recovering Nonviolent History: Civil Resistance in Liberation Struggles, ed. Maciej J. Bartkowski (Boulder, CO: Rienner, 2013).

65 Draft press communiqué after 1958 elections, in: LGH 1/2/1 Urban African Housing Area Boards Regs., 1948-1961, NAZ.

66 See, for instance, debate about African representation at Ndola, 30 October 1956, in: LGH 1/18/19 African Affairs. African Representation. Written Evidence, 1956, NAZ; Mr. Roberts, Member for Lands and Local Government, in LegCo debate, Hansard 92x, 7 August 1957, in: MLSS 1/24/14, NAZ; "Widening Municipal Franchise”, Central African Post, 14 November 1961, in: LGH 1/5/17 Participation of Africans in Local Government. Report and Minutes of Evidence, 1961-1962, NAZ. 
the provision of housing was kept under control because authorities feared people could form strong communities, no longer migrating, which could instigate a feeling of community. As members of such a community they could feel entitled to vote. ${ }^{67}$ In Northern Rhodesia the discourse focused on urban Africans paying neither rent nor property rates and thus not being entitled to the franchise.

Yet things were in transition. There was a tendency towards the later 1950s already for councils and urban advisory bodies dominated by both colonial and settler interests to nominate members of the newly educated elite at the expense of representatives of the so-called traditional elite who had originally dominated these bodies. The hope was that this way nationalist leaders and their politics would be barred from advancing into political office. This, in turn, weakened the institutions in the eyes of those constituencies which, in accordance with the idea of "indirect rule," expected African representatives to be connected to royal families. ${ }^{68}$

In February 1957, four years into the existence of the Central African Federation, the Brown Report was presented. It had been commissioned by the Legislative Council in December 1955 and responded to pressure emerging from the demands of people taking to African nationalist parties. For the first time in the Northern Rhodesian history of government commissions, all members of the working group were resident in Northern Rhodesia, many of them throughout their lives, and in this composition, so the eager expectation, they captured a multiracial and deep local experience. The Brown Report suggested that African workers receive an all-in wage, including a cash element from which they would pay their own rent. To the disappointment of the more liberally minded, the Brown Report refrained from recommending direct African representation - even though it did consider more active parts for Africans to play in the administration of their housing areas. ${ }^{69}$ In the subsequent debate of the Legislative Council, the argument arose that the recommendations provided strong incentives for Africans who wanted to live in town permanently, who were among the aspiring and interested in social and political participation in the urban setting and its institutions. The conservative counter-argument held that still too many unwanted Africans would people the towns:

67 Adam Ashforth, The Politics of Official Discourse in Twentieth-Century South Africa (Oxford: Clarendon Press, 1990), 114-148.

68 Walima Kalusa, "Traditional Rulers, Nationalists and the Quest for Freedom in Northern Rhodesia in the 1950s," in Living the End of Empire: Politics and Society in Late Colonial Zambia, ed. Giacomo Macola, Jan-Bart Gewald, and Marja Hinfelaar (Leiden: Brill, 2011), 81.

69 Mr. Botha, Nkana representative, and Mr. Sokota, African Member, in LegCo debate, Hansard 92x 7 August 1957, in: MLSS 1/24/14, NAZ. 
We have the other type of African who comes into the townships in order to have a look at the lights, to fit himself out with a new outfit, and to go back to the village with his pocket duly lined; he does not require a house of any particularly good standard. If, therefore, the employee himself is responsible for paying his rent he himself will choose which type of house he wants to live in and not merely accept that his employer is paying for it and so not have any regards whatsoever as to what it costs or as to what type is to be supplied. ${ }^{70}$

The debate had shifted from earlier issues of labor stabilization to more openly expressed complaints of residents with self-asserted urban identities. Over the years, it had become evident that African workers did not need an incentive to come and stay in the towns. Instead, they needed means and an infrastructure to stay there and in their houses once they got unemployed or changed employers. All of a sudden, discussions around rent implied the reconceptualization of African representation - and vice versa. Should Africans become part of the administration by making them collect the rents, or should they take on complete financial responsibility? Would this endow them with the right of political representation? These considerations merged with a debate whether the strengthening of urban administrative structures should be achieved through Area Boards, on which nominated members would sit, or through actual Area Committees into which a certain proportion of Africans would be elected. ${ }^{71}$ As was the case with many debates at this time, arguments were intense for the time being but it took much longer to redesign the actual ways politics and board compositions unfolded in practice. Irrespective of their outcome, however, they indicate that political change was a slow, tough, and tenacious process and that issues of housing and rent had become deeply implicated in future rights to permanence in the towns and political representation in the country.

Perhaps not coincidentally, the debate gathered pace once the Colonial Office announced to withdraw funds which, for the municipalities, made the arrangement of sub-economic rents a policy not worthwhile pursuing. The situation was exacerbated because African residents pressed for electricity, water points, roads, and other services. In fact, another commission had to take up the question of African representation a few years onwards again. This time, direct representation was inevitable. That Africans should be allowed to vote for Africans on the African Area Housing Boards was conceded without much

70 Hansard, Legislative Council transcript, 7 August 1957, in: MLSS 1/24/14, NAZ.

71 Hansard, Legislative Council transcript, 7 August 1957, in: MLSS 1/24/14, NAZ. Area Boards or Area Committees would engage with the African Affairs Committee of the Municipal Council. The African Affairs Committee would bring African and township issues into the main body where decisions were taken. 
opposition. Immediately, however, the ratio of representation on committees, boards, and other bodies came under dispute. More liberal proponents of direct representation considered a 50-50 representation possible. Others advocated for one-third of Africans and two-thirds of European members in each committee.

Debates about rent and representation were also tied up with ideas about responsible citizenship and consumption in a society in which an increasing number of commodities became available through cash payment. In fact, one of the argumentative strands in the ongoing controversy about whether to pay wages on a weekly or monthly basis was that by adding a housing allowance to the wage, and by perhaps even paying monthly rates, authorities and Northern Rhodesian settler society more generally would lose grip on how people would spend their wealth. Would they rent decent houses? Would they not get indebted? Africans were eager to get higher cash lump sums into their hands and employers were favorably disposed towards disciplining workers through wages rather than providing them with accommodation. ${ }^{72}$

Meanwhile, the payment of rent itself had become more complex. Even though employers had paid for housing, they were not necessarily responsible for paying charges and service fees for water, electricity, and other amenities. However, as long as water was received through public pipes and no metering took place, people could only understand it as part of charges covered by others for them. ${ }^{73}$ To them, it did not matter whether employers, local authorities or the municipality paid for these expenses. They themselves contributed to the wealth of the colony by making their labor cheaply available - and expected a return in the form of services. ${ }^{74}$ Technically, if meters were installed in houses, a certain amount of water was free of charge for tenants, and only if these limits were exceeded, households had to pay. ${ }^{75}$ To measure this was not a straightforward affair, either. As it turned out, electricity was sometimes part of the rent,

72 Hansard, Legislative Council transcript, 7 August 1957, in: MLSS 1/24/14, NAZ.

73 Report of the Working Party Appointed to Examine the Implications of Providing Electrical Reticulation in Certain African Housing Areas (1960), 17 March 1960, in: LGH 1/1/26 African Housing Areas - Working Party on Electricity. Reticulation, 1960-1962, NAZ; or Report of the Proceedings of the Thirteenth Annual Conference of the Municipal Association of Northern Rhodesia and Nyasaland, held at Kitwe, 4-6 May 1960, and several other minutes in: LGH 1/8/ 5 Local Government. Municipal Association. Annual Conference, 1961, NAZ.

74 Memorandum “African Representation on Municipal and Township Councils”, dated 1956 and submitted by R. M. Nabulyato, in: LGH 1/18/19, NAZ.

75 Municipal Association of Northern Rhodesia and Nyasaland, Report of the Secretary to the Executive Committee, 5 July 1962, in: LGH 1/8/9 Municipal Association of Northern Rhodesia, Executive Committee: Minutes, 1961-1962, NAZ. 
sometimes it was not. This inscrutable situation turned into an issue of debate when the collection of rent, fees, and charges became the first responsibility handed over to the so-called Township Management Boards - and one understands why settler-dominated bodies wanted to get rid of such affairs.

In a next step, after June 1958, the Colonial Office and, consequently, the colonial government in Lusaka finally ceased to subsidize rents. Like in some earlier fruitless efforts, for a moment, house ownership for Africans was more prominently discussed, promoting the idea that, freed from rent and elevated into being propertied persons, house owners would gain security in their class position and evolve as a group "who can play a useful part in local government."76 Yet, reality played out in a different way. Local governments and municipalities had to increase rents which were - as in Livingstone, for instance - mainly met by smaller and middle-sized employers anyway. ${ }^{77}$ There was no way of knowing who of the residents were self-payers so that the collection of rent remained, if not impossible, at least very difficult. Some four percent of it, so the estimate, had to be written off monthly. ${ }^{78}$ The fact that after 1958, workers were expected to pay their own rent (or were entitled to pay it) did not mean that employers automatically added a housing allowance to their workers' wages. Sometimes, increased rent was deducted from laborers' tickets or their weekly pay. In other instances, laborers paid rent to the Local Authority and were compensated by their employers with a limited proportion only. Workers who, in view of these inconsistencies, complained to the Labor Officer were instantly sacked. ${ }^{79}$ This prevented rent from becoming a responsibility of citizens claiming, through the act of rent-paying, rights, and security of dwelling in town.

Again, the debate around African civil service differed from how African workers' situation was affected. African civil servants and clerks were a large and diversified group whose earnings could be as small as a few shillings paid per day or as substantial as some $£ 50$ per month. This grand variety of scale proved complicated to translate into general housing allowances or entitlements to housing classified to each respective rank. ${ }^{80}$ The situation created

76 Municipal Association of Northern Rhodesia, Minutes of the Eleventh Annual Conference, Livingstone 21-23 May 1958, in: LGH 1/8/2 Municipal Association of Northern Rhodesia. Annual Conferences, 1957-1960, NAZ.

77 Minutes of a Meeting, 6 May 1958, in: SP 1/4/14, NAZ.

78 Report of the Secretary to the Executive Committee, 1 October 1963, in: LGH 1/2/72, NAZ.

79 Hansard 94, 5 May 1958, and broadcast speech of C.E, Cousins, Labour Commissioner, 28 April 1958, as well as Mr. Sokoto's remark in MLSS 1/24/14, NAZ.

80 Minute to Brown Report, 1 March 1957, in: MLSS 1/24/14, NAZ. 
debate when the civil service became more thoroughly Africanized. While the opinion of African civil servants as of now seems irretrievable from the archival record, for the state it was clearly untenable to continue the provision of overpaid rental housing for all Africans entering the ranks of the service previously held by Europeans. There were ideas to subdivide existing houses of European standards into units fitting three or four African families. ${ }^{81}$ This is to assume, however, that expectations were more difficult to curb than standards. It was evident that the government would have to further provide rental rather than owner-occupied accommodation for its staff due to the numerous transfers while in office. ${ }^{82}$ For years to come, civil servants remained reluctant to "sink ... large sums in longterm investment." 83

It was in 1959 that a three-year period started when

the future of Northern Rhodesia was ultimately decided [...] as Britain, the increasingly reluctant colonial power, was squeezed by rising white settler calls for a racially-based Dominion, on the one hand, and nationalist demands for a rapid transition to independence on the other. ${ }^{84}$

As finances became more difficult to consolidate on the spot, the Minister of Local Government and Social Welfare admonished the African Township Management Boards sharply about failing to make township residents pay the rates and rents they were supposed to contribute. In all explicitness, he stressed that this would preclude them from claiming rights-bearing citizenship. ${ }^{85}$ While most African nationalists and liberal British observers imagined the future of Northern Rhodesia as a unified territory governed by majority self-rule, white rulers of the Federation and some conservative British officials contemplated the redrawing of borders and separating the Copperbelt and urban commercial areas along the railway line from the rest of the colony. A lengthy period of delicate negotiations ensued with intensive lobbying on all sides. Danger loomed that settler hostility against a constitution, which granted Africans substantial political power, would thwart the whole

81 Some Notes on Housing for the Local Civil Service, c. 1962, in: LGH 1/24/20 Housing Local Civil Service, 1961-62, NAZ.

82 Various correspondence and minutes, in: MLSS 1/24/20, NAZ.

83 Notes on Housing for the Local Civil Service, c. 1962, in: MLSS 1/24/20, NAZ.

84 Miles Larmer, Rethinking African Politics: A History of Opposition in Zambia (Farnham: Ashgate, 2011), 32.

85 “Township 'Confab', Central African Post, 20 November 1959 and "Africans must realise the basis of citizenship is to pay its way," Northern News, 20 November 1959, as well as opening speech printed in Minutes of the Tenth Annual Conference of the African Township Management Boards, Mukubeko, 20 October 1960, in: LGH 1/9/2 Local Government: Conference - African Townships, 1959-1963, NAZ. 
process. In the end, a complex electoral system was agreed upon. It ensured that for part of their candidates, African national parties had to attract support from European settlers as well and vice versa - that certain seats could only be required for Europeans if they secured a minimum number of African votes. Accelerated progress towards self-rule in the colony rested on the defense of the privileged political representation of white settlers and hence, an African nationalist majority in the new Legislative Council was virtually impossible. ${ }^{86}$ Yet, despite these stumbling blocks, the mid-1962 elections set the colony on its path towards independence.

The provision of rented accommodation or houses available on alternative terms never ceased to run as a debate in the background. To ease transitions, the Government introduced a scheme which provided for the long-term lease of land in African townships. The newly organized leases were intended to add security to tenure and to make the collection of rent a possible venture. In October 1962, preparations started that by July the following year, tenants should have, at a minimum, a one-year Crown Annual tenancy issued by the Ministry of Land and Natural Resources. Generally, however, the idea was to issue ten-year leases. ${ }^{87}$ It was also planned that with the new leases local authorities would become responsible for the handling of rent - well knowing that "the income collection systems of African Township Management Boards have, unfortunately, proved to be one of the weakest parts of their administration." ${ }^{88}$ The wording of the notices intended to end the current system of renting, while introducing the new one was strict and bore a tone of authoritarianism. Officials from the local bureaucracy, whose attitudes on the spot were guided by pragmatism and knowledge of what was possible to achieve, objected and suggested to "tone [the wording] down a little to avoid much ill-will in the Townships at a time when we are surely hoping to foster good-will." 89 This intervention reveals that at this stage the

86 Mulford, Zambia, 178-197, 229-300.

87 Circular of Ministry of Land and Natural Resources, Lusaka, 27 October 1962, to Senior Provincial Commissioners, District Officers, Township Officers, Ministry of Local Government and Social Welfare, in: LGH 1/2/60 African Townships. Building Schemes under Section 14B Township Ordinance, 1963, NAZ.

88 Correspondence of Permanent Secretary, Ministry of Lands and Natural Resources, to Permanent Secretary, Ministry of Local Government and Social Welfare, 9 October 1962, in: LGH 1/2/60, NAZ; Finance Circular No. MF/3640/2 Vol. II, 16 January 1961, in: MLSS 1/24/18 Housing Government Employees. General, 1960-1968, NAZ.

89 Circular of Ministry of Land and Natural Resources, 27 October 1962, in: LGH 1/2/60, NAZ; for quote refer to S. L. G. F .O., Ndola, to Permanent Secretary, Lusaka, 13 November 1962, in: LGH 1/14/33 Leases African Townships, 1961-1962, NAZ. 
scope to maneuver in a field of forces was evidently biased towards township residents rather than in the hands of colonial agents. In fact, it soon turned out that the tenants' responses to this incentive were disappointing. ${ }^{90}$ This was partly due to the cost involved. People had to pay rent plus a fee for the agreement plus additional board fees. Many did not want long-term leases but preferred the option of changing places and staying mobile. They had learned through experience that any new scheme would last only sporadically. ${ }^{91}$ So why invest resources this time? There were good reasons to first wait and see.

This notwithstanding, the ruling powers insisted on redefining the meaning of housing:

In nearly all countries individuals are responsible for providing their own housing. The standard of the house in which they live and the area in which it is situated is a matter of personal choice and is dictated almost entirely by the proportion of his income which the individual is prepared to devote to housing himself and his family. The present system of Government-provided housing inevitably produces pressures, both from individual and the Civil Service organisations, for Government to provide ever increasing standards. ${ }^{92}$

As usual, the blame went on African tenants irrespective of the new conviction that "[ $t$ ]he best hope of achieving new and realistic levels in housing is for the Companies to divest themselves of the responsibility of providing houses so that normal economic factors come into play and employees occupy houses of their choice in accord with their earnings."93

In this transition period, the building of medium grade African houses to be leased in the same manner as European houses proved especially problematic. It was impossible to bill tenants for rent, electricity, and water charges if before they had not sought exemption from the regulations of the Employment of Natives Ordinance. There was no rule as to what tariffs had to be applied. The Commissioner for Local Government and, in a somewhat different vein, the Ministry of Labour and Mines decided that even if water was to be metered and paid for, electricity would perhaps be payable through the employer - provided he consented to this. If, however, some of the houses would be occupied by

90 Circular of Ministry of Land and Natural Resources, 27 October 1962, in: LGH 1/2/60, NAZ. 91 District Commissioner, N. A. Baguley, to Secretary, Ministry of Local Government and Social Welfare, Ndola, 26 November 1962 and S. L. G. F .O., Ndola, to Permanent Secretary, Lusaka, 13 November 1962, in: LGH 1/14/33, NAZ.

92 Notes on Housing for the Local Civil Service, c. 1962, in: MLSS 1/24/20, NAZ. 93 Notes on Housing for the Local Civil Service, c. 1962, in: MLSS 1/24/20, NAZ. 
African civil servants, other rules would apply as yet another set of rules would have to be considered if self-employed African entrepreneurs moved in. ${ }^{94}$

Almost concomitantly, a debate emerged with regard to voting rights. In the process of incorporating more Africans, especially urban ones, into the system of a qualified franchise, H.J.E. Stanley, Member of Legislative Council, suggested to reduce the limit of property or earned income to $£ 300$ (instead of previously £750). This would have allowed owners of a normal two-bedroomed house to qualify for the franchise. ${ }^{95}$ Moreover, self-payers of rent came within the reach of the vote. No longer should it matter whether people actually owned property or whether they paid rent for such a property. As long as they had been resident in town for at least six months, paid rent regularly, and were not in arrears they should receive the vote. ${ }^{96}$ Stanley's radical re-evaluation showed that the towns both lacked funds and needed to integrate a new clientele eager to participate in urban politics. About this time, rent ceased to be a medium through which to assess how colonial rule unfolded between most actors in the Northern Rhodesian societal field of force. It had changed its meaning, and colonial rule would henceforth be graspable through other relations of power.

\section{Conclusions}

As people came to town and had to look for accommodation, once they did not stay with kin rent was woven into their daily affairs. It was a tie kept by the various authorities and by employers as a bond of dependence and remained under the grip of formal employers and the municipalities. Rent also kept the municipalities tied to the subsidies paid and forwarded by the central government as financially and economically the management of rent was not a gainful endeavor. Throughout the late colonial period rent did not become a publicly politicized concern in the immediate sense. Tied to it, however, was a range of political debates such as permanence in towns, voting rights, and achievement of status through ownership, or alternative forms of tenure security.

Between 1948 and 1962, rent dramatically changed its meaning. It had evolved from being an intended tool of keeping workers acquiescent into a

94 Report of the Secretary to the Executive Committee, 5 July 1962 - Bancroft, in: LGH 1/8/9, NAZ. 95 For changing qualifications to achieve the vote see Mulford, Zambia, 49, 56-61; for debate see Minute of oral evidence and written memoranda submitted to the Committee appointed to inquire into "The Participation of Africans in Local Government in Municipal and Township Areas,” October 1960, in: LGH 1/5/17, NAZ.

96 Stanley's evidence and memorandum in a written report, undated, in: LGH 1/5/17, NAZ. 
payment considered empowering to participate in responsible urban politics and the national franchise. From being an element of social welfare, which enforced a union between state and employers, it became a burden the late colonial state was unable to handle and employers reluctant to shoulder. The focus on rent provides a telling lens on understanding shifts in conceptions of power, rule, good-will, and obedience. To talk about rent opens up possibilities to think about power and rule more independently from the established master narrative of ownership housing schemes mattering elsewhere.

To use the notion of power, rule, and obedience unfolding in a Northern Rhodesian societal field of force allows looking, through rent, at relations unfolding and shifting power biases between multiple actors. Rent in Northern Rhodesia itself was an indication of a paternalist form of rule. This paternalism did not completely cease throughout the period under review. But after the establishment of the Central African Federation - and while the African nationalist movement was gathering momentum by protesting against the unification of the three territories - paternalism lost ground, and against this backdrop the payment of rent became ever more complex and complicated until it even served as a means of thinking about it as equivalent to property values. Employers, yet again, needed to rely on other means than housing to safeguard their companies' position in the colonial economy.

Rent thus provides a lens through which to assess the changing dynamics of power and rule. It is a lens heavily entangled with a number of debates which all feed into the amalgamated, and at time convoluted, experience of colonialism in Northern Rhodesia. In the end, this convoluted nature of the debates protruding into the lens alerts us to the fact that the history of rent cannot be told as a history of its own. It is deeply ingrained in the political as well as in the everyday spheres of what housing under colonialism meant to a society moving towards independence.

\section{References}

\section{Archival sources}

\section{National Archives of Zambia, Lusaka (NAZ)}

\section{Ministry of Mines and Labour and Social Services (MLSS)}

1/24/2 Housing: Native Locations. Private Locations, 1944-1955.

1/24/7 Labour Department: African Housing (Unauthorised Locations), 1955-1961.

1/24/14 Employment of Natives and “Housing Conditions”, 1957-1959. 
1/24/18 Housing Government Employees. General, 1960-1968.

1/24/20 Housing Local Civil Service, 1961-1962.

\section{Ministry of Local Government and Housing (LGH)}

1/1/26 African Housing Areas - Working Party on Electricity. Reticulation, 1960-1962.

1/1/30 Unauthorised Locations, 1960-1968.

1/2/1 Urban African Housing Area Boards Regs., 1948-1961.

1/2/60 African Townships. Building Schemes under Section 14B Township Ordinance, 1963.

1/2/72 Township Regulations, 1963-1966.

1/5/17 Participation of Africans in Local Government. Report and Minutes of Evidence, 1961-1962.

1/8/1 Local Government: Municipal Association General, 1952-1963.

1/8/2 Municipal Association of Northern Rhodesia. Annual Conference, 1957-1960.

1/8/5 Local Government. Municipal Association. Annual Conference, 1961.

1/8/9 Municipal Association of Northern Rhodesia, Executive Committee: Minutes, 1961-1962.

1/9/2 Local Government: Conference - African Townships, 1959-1963.

1/14/33 Leases African Townships, 1961-1962.

1/16/49 Housing for Eurafricans, 1949-1953.

1/16/52 Local Government: African Housing, General Policy, 1952-1953.

1/16/53 African Housing, Atkinson Report, 1953.

1/18/19 African Affairs. African Representation. Written Evidence, 1956.

3/2/9 Livingstone: Areas and Boundaries, 1951-1959.

3/25/17 Urban Advisory Councils, Welfare Associations General, and Other Associations, 1956-1960.

\section{Southern Province (SP)}

1/4/14 Alienation of Land and Township Plots, 1948-1952.

4/1/30 Municipality of Livingstone. Minutes of Native Affairs Sub-Committee Meetings, 1947.

4/1/26 Municipality of Livingstone. Minutes. Public Works - Sub-Committee, 1946-1955

4/1/33 Municipality of Livingstone. Minutes of Native Affairs Sub-Committee Meetings, 1948.

4/3/6 Municipality of Livingstone, Native Affairs Sub-Committee, 1946.

4/3/14 Housing Committee, Mazabuka, 1955-1958.

4/6/10 Urban Advisory Councils and Welfare Associations - General, 1952-1956.

\section{The National Archives, Kew (TNA)}

\section{Colonial Office (CO)}

CO 795/123/4 Copperbelt Labour Supplies. Housing Question, 1942-1943.

CO 927/35/3 Housing Research, Central Africa, 1945-1947.

\section{Secondary literature}

Ashforth, Adam. The Politics of Official Discourse in Twentieth-Century South Africa. Oxford: Clarendon Press, 1990. 
Bennett, Frank. Under an African Sun: Memoirs of a Colonial Officer in Northern Rhodesia. London: Radcliffe, 2005.

Bissell, William Cunningham. Urban Design, Chaos, and Colonial Power in Zanzibar. Bloomington, IN: Indiana University Press, 2011.

Bond, Mick. From Northern Rhodesia to Zambia: Recollections of a DO/DC 1962-73. Oxford: Gadsden Publishers, 2014.

Brennan, James R. Taifa: Making Nation and Race in Urban Tanzania. Athens, $\mathrm{OH}$ : Ohio University Press, 2012.

Buettner, Elizabeth. Empire Families: Britons and Late Imperial India. Oxford: Oxford University Press, 2005.

Chaskalson, Matthew, Karen Jochelson, and Jeremy Seekings. "Rent Boycotts, the State and the Transformation of the Urban Political Economy in South Africa." Review of African Political Economy 40 (1987): 47-64.

Chileshe, Jonathan H. Alderman Safeli Hannock Chileshe: A Tribute to (the Man), His Life, and History. Ndola: Mission Press, 1998.

Cohen, Andrew. "Business and Decolonisation in Central Africa Reconsidered." Journal of Imperial and Commonwealth History 36, no. 4 (2008): 641-658.

Cooper, Frederick, and Randall Packard. "Introduction." In International Development and the Social Sciences: Essays on the History and Politics of Knowledge, edited by Frederick Cooper and Randall Packard, 1-41. Berkeley, CA: University of California Press, 1997.

Crehan, Kate, and Achim von Oppen. "Understandings of 'Development': An Arena for Struggle. The Making of a Development Project in North-Western Province." In Planners and History: Negotiating 'Development' in Rural Zambia, edited by Kate Crehan and Achim von Oppen, 257-305. Lusaka: Multimedia Publications, 1994.

Datta, Kusum. "Farm Labour, Agrarian Capital and the State in Colonial Zambia: The African Labour Corps, 1942-52.” Journal of Southern African Studies 14, no. 3 (1988): 371-792.

Englund, Harri. "Anti Anti-Colonialism: Vernacular Press and Emergent Possibilities in Colonial Zambia." Comparative Studies in Society and History 57, no. 1 (2015): 221-247.

Ferguson, James. Expectations of Modernity: Myths and Meanings of Urban Life on the Zambian Copperbelt. Berkeley: University of California Press, 2001.

Gewald, Jan-Bart. "Researching and Writing in the Twilight of an Imagined Conquest: Anthropology in Northern Rhodesia 1930-1960." History and Anthropology 18, no. 4 (2007): 459-487.

Hansen, Karen Tranberg. Distant Companions: Servants and Employers in Zambia, 1900-1985. Ithaca, NY: Cornell University Press, 1989.

Home, Robert K. Of Planting and Planning: The Making of British Colonial Cities. 2nd edition. Oxford: Routledge, 2013.

Huchzermeyer, Marie. "Tenement City: The Emergence of Multi-Storey Districts Through LargeScale Private Landlordism in Nairobi." International Journal of Urban and Regional Research 31, no. 4 (2007): 714-732.

Kalusa, Walima. "Traditional Rulers, Nationalists and the Quest for Freedom in Northern Rhodesia in the 1950s." In Living the End of Empire: Politics and Society in Late Colonial Zambia, edited by Giacomo Macola, Jan-Bart Gewald, and Marja Hinfelaar, 67-90. Leiden: Brill, 2011.

Kamete II, Amin Y. "Civil Society, Housing and Urban Governance: The Case of Urban Housing Co-operatives in Zimbabwe." In Associational Life in African Cities: Popular Responses to 
the Urban Crisis, edited by Arne Tostensen, Inge Tvedten, and Mariken Vaa, 162-179. Stockholm: Nordiska Afrikainstitutet, 2001.

Larmer, Miles. Rethinking African Politics: A History of Opposition in Zambia. Farnham: Ashgate, 2011.

Lüdtke, Alf. “Einleitung: Herrschaft als soziale Praxis.” In Herrschaft als soziale Praxis: Historische und sozial-anthropologische Studien, edited by Alf Lüdtke, 9-63. Göttingen: Vandenhoek \& Ruprecht, 1991.

Momba, Jotham C., and Fay Gadsden. "Zambia: Nonviolent Strategies Against Colonialism, 1900s-1960s." In Recovering Nonviolent History: Civil Resistance in Liberation Struggles, edited by Maciej J. Bartkowski, 71-88. Boulder, CO: Rienner, 2013.

Mpashi, Stephen A. Betty Kaunda. Lusaka: Longmans, 1969.

Mulford, David C. Zambia: The Politics of Independence 1957-1964. Oxford: Oxford University Press, 1967.

Mutale, Emmanuel. The Management of Urban Development in Zambia. Farnham: Ashgate, 2004.

Mwanakatwe, John M. Teacher, Politician, Lawyer: My Autobiography. Lusaka: Bookworld Publications, 2003.

Mwangi, Meja. The Cockroach Dance. 2nd edition. Columbus, Ohio: HM Books Intl., 2017.

Nabulyato, Robinson M. African Realities: A Memoir. Edited by Giacomo Macola. Lusaka: The Lembani Trust, 2008.

Parpart, Jane. Labor and Capital on the African Copperbelt. Philadelphia: Temple University Press, 1983.

Phimister, Ian. "Proletarians in Paradise: The Historiography and Historical Sociology of White Miners on the Copperbelt." In Living the End of Empire: Politics and Society in Late Colonial Zambia, edited by Giacomo Macola, Jan-Bart Gewald, and Marja Hinfelaar, 141-160. Leiden: Brill, 2011.

Phiri, Bizeck Jube. A Political History of Zambia: From Colonial Rule to the Third Republic, 1890-2001. Trenton, NJ: Africa World Press, 2006.

Rakodi, Carole. "Rental Tenure in the Cities of Developing Countries." Urban Studies 32, no. 4-5 (1995): 791-811.

Ranger, Terence. Bulawayo Burning: The Social History of a Southern African City, 1893-1960. Suffolk: Boydell \& Brewer, 2010.

Roberts, Andrew. A History of Zambia. London: Heinemann, 1976.

Stoler, Ann Laura. Along the Archival Grain: Epistemic Anxieties and Colonial Common Sense. Princeton: Princeton University Press, 2009.

Sungura, Nicholas. "Der Faktor Mensch bei der Risikosteuerung öffentlicher Bauvorhaben in Kenia.” Dr. Eng. diss., University of Hannover, 2016.

Thompson, E. P. "Eighteenth-Century English Society: Class Struggle without Class?” Social History 3, no. 2 (1978): 133-165.

Tosh, John. “Imperial Masculinity and the Flight from Domesticity in Britain, 1880-1914." In Gender and Colonialism, edited by Timothy P. Foley et al., 72-85. Galway: Galway University Press, 1995.

Vladislavic, Ivan. The Exploded View. Cape Town: Umuzi, 2017. 